\title{
Awareness, Enrollment and Utilization of Health Insurance Scheme among Adults of Pokhara
}

\author{
Dibya Sharma, ${ }^{1}$ Priyanka Basnet, ${ }^{2}$ Ramchandra Kafle ${ }^{3}$ \\ 'School of Nursing, Manipal College of Medical Sciences, Pokhara, Nepal, ²Oncology ward, B \& B hospital, Kathmandu, Nepal, \\ ${ }^{3}$ Department of Cardiology, Manipal Teaching Hospital, Phulbari - 1 1, Pokhara, Nepal.
}

\begin{abstract}
Introduction

Some illnesses can imposehuge economic burden on individuals and families. Expensive health care discourages people to use health services, generating prolonged or worsened health problems. Financial burden can be managed wisely paying small premium which would lessen stress in medical emergencies.The objective is to assess awareness, enrollment and utilization of health insurance scheme and find out association between awareness and enrollment with demographic variables.
\end{abstract}

\section{Methods}

A cross sectional study was conducted to assess awareness, enrollment and utilization of health insurance among adults of Phulbari-11, Pokhara. Study was conductedfrom June 2019 - August 2019 among 153 adult using convenient sampling. Permissionwas obtained from Institutional Review Committee, Manipal and verbal informed consent was taken from respondents prior todata collection. Data was analyzed using descriptive and inferential statistics using Statistical Package for Social Sciences (SPSS) version 18.0.

\section{Results}

About $45.1 \%$ were awareabout health insuranceand $40 \%$ had enrolled in it. Among them, more than $2 / 3^{\text {rd }}(69 \%)$ had procured service at least once.Individual awareness wasstatistically significant with ethnicity. Enrollment in health insurance is significantly associated with age, ethnicity, marital status, history of chronic illness, family history of chronic illness and awarenesswith $95 \%$ $\mathrm{CI}$ at $\mathrm{p}$ value $\leq 0.05$.

\section{Conclusions}

Individual awareness, enrollment and utilization of scheme are less.So, there is strong necessity to raiseawareness level, convincing them to enroll in any type of scheme based on their ability to pay, ensuring proper utilization of health care after getting enrolled by proactively educating community people.

Keywords: awareness; enrollment; health insurance; utilization.

Correspondence: Dibya Sharma, Nursing Program, Manipal College of Medical Sciences, Phulbari-1 1, Pokhara, Nepal. Email: dibyasharma01@gmail.com, Phone:+977-9856054493. 


\section{INTRODUCTION}

Some type of illnesses can impose a huge economic burden on individuals and families. ${ }^{1}$ Expensive health care discourages people to use health services, generating prolonged or worsened health problems particularly among the poor population. ${ }^{2}$ Approximately 150 million people suffer from financial burden each year due to health care payments, and about 100 million are pushed into poverty. ${ }^{3}$ Most health care in Nepal is paid out-of-pocket often incurring significant portion of the income of individual household leading to catastrophic health expenditure. Previous studies in Nepal showed that, $13.8 \%$ of the households had experienced catastrophic expenditure on health. ${ }^{4}$ Protecting people from appalling health care expenses thereby preventing people from dwindling into poverty trap has been a topic of discussion in Nepal in recent times. ${ }^{5}$ So the objective of study is to assess awareness, enrollment and utilization of health insurance and find out the association between awareness and enrollment with demographic variables.

\section{METHODS}

A cross sectional study was conducted to assess the awareness, enrollment and utilization of health insurance scheme from adults of Phulbari -11, Pokhara, Nepal from $1^{\text {st }}$ June $-30^{\text {th }}$ August 2019.

The sample size for the study was calculated using formula $\mathrm{z}^{2} \mathrm{pq} / \mathrm{l}^{2}$ (taking $\mathrm{p}$ as $75 \%$ reference from a study of Bangalore, India ${ }^{6}$ and 1 as allowable error $7 \%$ ) which accounts to be 153 . Non-probability convenient sampling technique was applied to collect the sample from that specific ward. The questionnaire/ Performa used comprise of 4 sections. Sections 1 deal with socio-demographic variable, section 2 evaluate the awareness, 3 assess enrollment and 4 estimate the utilization of health service. Section 2 which assess the awareness of health insurance consists of 25 items and is categorized based on the mean score as Yes (21 - 25) and No (0 - 20).

Logical sequence of questionnaire was maintained and checked for content validity. As per the suggestion of the subject experts and literature review, necessary modifications were made in the tool. Pretesting was done on $10 \%$ of the study population in Phulbari-11 i.e. 15 and Crohnbach alpha was calculated to checked the reliability of the tool which was found to be 0.75 . The data of the pretesting was excluded from the main study.

The data was collected by door-to-door survey via face-to-face interview using a semistructured questionnaire. Individual of age $\geq 18$ years and were willing to participate in the study were included. The households that were locked and where the age criteria were not fulfilled were excluded. An individual was taken from each house. On an average, 14 respondents were taken every day for 2 weeks.

Permission to conduct the study was obtained from Institutional Review Committee, Manipal Teaching Hospital, Pokhara, Nepal. Verbal informed consent was taken from the respondents prior to data collection. Confidentiality and anonymity was maintained by removing personal identifiers and not disclosing information to anyone except for research purpose. Respondents dignity was maintained by giving right to discontinue from the study at any time.

After collecting, the data was checked for completeness and accuracy and entered in MS excel and analyzed by SPSS (statistical package for social sciences) version 18. The data was presented in mean, frequency distribution, percentage and standard deviation. The distribution of the variables was assessed 
using the Kolmogorov-Smirnov test, and Levene's test was performed to assess variance equality. Inferential statistics like chi square test and t-test were used to find the association between awareness and enrollment with sociodemographic variables. Differences were considered statistically significant at $95 \%$ confidence interval i.e. $\mathrm{p}$ value $<0.05$.

\section{RESULTS}

Nearly $61 \%$ of the respondents were young adult (18 - 35 years). About 2/3 $3^{\text {rd }}(66 \%)$ of the respondents were female. Majority of the respondents $(82.4 \%)$ had received some form of formal education. More than $3 / 4^{\text {th }}(75.8 \%)$ of the respondents had no history of chronic illness (Table 1)

Table 1. Baseline characteristics of the respondents. $(n=153)$

\begin{tabular}{|c|c|c|}
\hline Socio-demographic variables & Frequency(f) & Percentage (\%) \\
\hline $\begin{array}{l}\text { Age(years) } \\
18-35 \\
>35 \\
\text { Mean } \pm S D\end{array}$ & $\begin{array}{c}93 \\
60 \\
34.76 \pm 10.837\end{array}$ & $\begin{array}{l}60.8 \\
39.2\end{array}$ \\
\hline $\begin{array}{l}\text { Gender } \\
\text { Female } \\
\text { Male }\end{array}$ & $\begin{array}{c}101 \\
52\end{array}$ & $\begin{array}{l}66 \\
34\end{array}$ \\
\hline $\begin{array}{l}\text { Ethnicity } \\
\text { Brahmin/Chhetri } \\
\text { Janajati } \\
\text { Dalit }\end{array}$ & $\begin{array}{l}73 \\
60 \\
20\end{array}$ & $\begin{array}{l}13.1 \\
39.2 \\
47.7\end{array}$ \\
\hline $\begin{array}{l}\text { Religion } \\
\text { Hinduism } \\
\text { Others (Buddhist/Christian/Muslim) }\end{array}$ & $\begin{array}{c}136 \\
17\end{array}$ & $\begin{array}{l}88.9 \\
11.1\end{array}$ \\
\hline $\begin{array}{l}\text { Marital status } \\
\text { Married } \\
\text { Others (Unmarried/widow/divorced) }\end{array}$ & $\begin{array}{c}128 \\
25\end{array}$ & $\begin{array}{l}83.7 \\
16.3\end{array}$ \\
\hline $\begin{array}{l}\text { Educational level } \\
\text { Formal education } \\
\text { Informal/Illiterate }\end{array}$ & $\begin{array}{c}126 \\
27\end{array}$ & $\begin{array}{l}82.4 \\
17.7\end{array}$ \\
\hline $\begin{array}{l}\text { Occupational status } \\
\text { Employed } \\
\text { Unemployed }\end{array}$ & $\begin{array}{l}81 \\
72\end{array}$ & $\begin{array}{l}52.9 \\
47.1\end{array}$ \\
\hline $\begin{array}{l}\text { Type of family } \\
\text { Nuclear } \\
\text { Joint/Extended }\end{array}$ & $\begin{array}{c}100 \\
53\end{array}$ & $\begin{array}{l}65.4 \\
34.6\end{array}$ \\
\hline $\begin{array}{l}\text { History of chronic illness } \\
\text { Yes } \\
\text { No }\end{array}$ & $\begin{array}{c}37 \\
116\end{array}$ & $\begin{array}{l}24.2 \\
75.8\end{array}$ \\
\hline $\begin{array}{l}\text { Family history of chronic illness } \\
\text { Yes } \\
\text { No }\end{array}$ & $\begin{array}{c}35 \\
118\end{array}$ & $\begin{array}{l}22.9 \\
77.1\end{array}$ \\
\hline
\end{tabular}


Less than half $(45.1 \%)$ of the respondents were aware about health insurance. About $40 \%$ of the respondents had enrolled in the health insurance scheme. Among them, more than $2 / 3^{\text {rd }}(69 \%)$ of the respondents had procured health insurance service at least once (Table 2).

Table 2. Awareness, enrollment and utilization of health insurance. $(n=153)$

\begin{tabular}{|l|l|l|}
\hline \multicolumn{1}{|c|}{ Variables } & $\begin{array}{c}\text { Frequency } \\
\text { (\%) }\end{array}$ & $\begin{array}{c}\text { Percentage } \\
\text { (\%) }\end{array}$ \\
\hline $\begin{array}{l}\text { Awareness } \\
\text { Yes }\end{array}$ & 69 & 45.1 \\
No & 84 & 54.9 \\
\hline $\begin{array}{l}\text { Enrollment(Insured) } \\
\text { in health insurance } \\
\text { Yes }\end{array}$ & 61 & 39.9 \\
No & 92 & 60.1 \\
\hline $\begin{array}{l}\text { Reason to purchase } \\
\text { the insurance(n= 61) } \\
\text { To meet out medical } \\
\text { expenses } \\
\text { Employee benefit }\end{array}$ & 55 & 6 \\
\hline $\begin{array}{l}\text { Source of information } \\
\text { on health insurance } \\
\text { (n= 61) } \\
\text { Health personnel } \\
\text { Others (Relatives / } \\
\text { friends/media) }\end{array}$ & 8 & 9.8 \\
\hline $\begin{array}{l}\text { Type of health } \\
\text { insurance procured } \\
\text { (n= 61) } \\
\text { Government } \\
\text { Private }\end{array}$ & 53 & 86.9 \\
\hline $\begin{array}{l}\text { Utilization of health } \\
\text { service (n= 61) } \\
\text { Yes }\end{array}$ & 7 & 13.1 \\
No & 39 & \\
\hline
\end{tabular}

There was significant association between awareness of the health insurance and ethnicity of the respondents at $p$ value 0.032 . Whereas, other variables like age, gender, religion, education, occupation, type of family, history of chronic illness and family history of chronic illness were not significantly associated with the awareness of the respondents (Table 3).

Table 3. Association of socio-demographic variables with awareness. $(n=153)$

\begin{tabular}{|c|c|c|c|}
\hline \multirow[t]{2}{*}{ Variables } & \multicolumn{2}{|c|}{ Awareness } & \multirow[t]{2}{*}{ p value } \\
\hline & Yes (\%) & No (\%) & \\
\hline Age(in years) & $34.58 \pm 10.957$ & $34.91 \pm 10.806$ & 0.852 \\
\hline Gender & & & \\
\hline Female & $56(55.5)$ & $45(45.5)$ & 0.851 \\
\hline Male & $28(53.8)$ & $24(46.2)$ & \\
\hline Ethnicity & & & \\
\hline Dalit & $13(65.0)$ & $7(35.0)$ & \\
\hline Janajati & $39(65.0)$ & $21(35.0)$ & $0.032^{\#}$ \\
\hline Brahmin/Chhetri & $32(43.8)$ & $41(56.2)$ & \\
\hline Religion & & & \\
\hline Hinduism & 73(53.7) & $63(46.3)$ & 0.389 \\
\hline Others* & $11(64.7)$ & $6(35.3)$ & \\
\hline Marital status & & & \\
\hline Married & $67(52.3)$ & $61(47.7)$ & 0.150 \\
\hline Others** & $17(68.0)$ & $8(32.0)$ & \\
\hline Educational level & & & \\
\hline Formal education & $69(54.8)$ & $57(45.2)$ & 0.940 \\
\hline Informal/Illiterate & $15(55.6)$ & $12(44.4)$ & \\
\hline Occupation & & & \\
\hline Employed & $43(53.1)$ & $38(46.9)$ & 0.632 \\
\hline Unemployed & $41(56.9)$ & $31(43.1)$ & \\
\hline Type of family & & & \\
\hline Nuclear family & $51(50.5)$ & $50(49.5)$ & 0.183 \\
\hline $\begin{array}{l}\text { Joint/Extended } \\
\text { family }\end{array}$ & $33(63.5)$ & $19(36.5)$ & \\
\hline History of chronic & & & \\
\hline illness & & & \\
\hline Yes & $20(54.1)$ & $17(45.9)$ & 0.905 \\
\hline No & $64(55.2)$ & $52(44.8)$ & \\
\hline $\begin{array}{l}\text { Family history of } \\
\text { chronic illness }\end{array}$ & & & \\
\hline Yes & $18(50)$ & $18(50)$ & \\
\hline No & $66(56.4)$ & $51(43.6)$ & 0.499 \\
\hline
\end{tabular}

* Buddhist/Christian/Muslim

Number in parenthesis indicate percentage and $p$ value $<0.05$ indicates significance 
Enrollment in the health insurance is significantly associated with age, ethnicity, marital status, history of chronic illness, family history of chronic illness and awareness on the health insurance scheme at $95 \% \mathrm{CI}$ i.e. $\mathrm{p}$ value $<0.05$ (Table 4).

\begin{tabular}{|c|c|c|c|c|}
\hline \multirow{2}{*}{ Variables } & \multicolumn{2}{|c|}{ Enrollment (Insured) } & \multirow[b]{2}{*}{ p value } & \multirow[b]{2}{*}{ COR $(95 \% \mathrm{Cl})$} \\
\hline & Yes & No & & \\
\hline Age(in years) & $38.11 \pm 10.825$ & $32.54 \pm 10.31$ & 0.002 & $5.57(2.139-9.00)$ \\
\hline $\begin{array}{l}\text { Gender } \\
\text { Female } \\
\text { Male }\end{array}$ & $\begin{array}{l}38(37.6) \\
23(44.2)\end{array}$ & $\begin{array}{l}63(62.4) \\
29(55.8)\end{array}$ & 0.430 & $\begin{array}{l}1.315(0.667-2.594) \\
\text { Ref. }\end{array}$ \\
\hline $\begin{array}{l}\text { Ethnicity } \\
\text { Dalit } \\
\text { Janajati } \\
\text { Brahmin/Chhetri }\end{array}$ & $\begin{array}{l}6(30) \\
12(20) \\
43(58.9)\end{array}$ & $\begin{array}{l}14(70) \\
48(80) \\
30(41.1)\end{array}$ & $<0.001$ & $\begin{array}{l}3.34(1.154-9.69) \\
5.733(2.61-12.58) \\
\text { Ref. }\end{array}$ \\
\hline $\begin{array}{l}\text { Marital status } \\
\text { Married } \\
\text { Others* }\end{array}$ & $\begin{array}{l}58(45.3) \\
3(12)\end{array}$ & $\begin{array}{l}70(54.7) \\
22(88)\end{array}$ & 0.002 & $\begin{array}{l}6.076(1.73-21.32) \\
\text { Ref. }\end{array}$ \\
\hline $\begin{array}{l}\text { Educational level } \\
\text { Formal } \\
\text { Informal/Illiterate }\end{array}$ & $\begin{array}{l}54(42.9) \\
7(25.9)\end{array}$ & $\begin{array}{l}72(57.1) \\
20(74.1)\end{array}$ & 0.108 & $\begin{array}{l}0.462(0.184-1.183) \\
\text { Ref. }\end{array}$ \\
\hline $\begin{array}{l}\text { Occupation } \\
\text { Employed } \\
\text { Unemployed }\end{array}$ & $\begin{array}{l}33(40.7) \\
28(38.9)\end{array}$ & $\begin{array}{l}48(59.3) \\
44(61.1)\end{array}$ & 0.815 & $\begin{array}{l}0.926(0.484-1.771) \\
\text { Ref. }\end{array}$ \\
\hline $\begin{array}{l}\text { Type of family } \\
\text { Nuclear family } \\
\text { Joint/Extended }\end{array}$ & $\begin{array}{l}36(35.6) \\
25(47.2)\end{array}$ & $\begin{array}{l}64(64.0) \\
28(52.8)\end{array}$ & 0.181 & $\begin{array}{l}1.587(0.807-3.122) \\
\text { Ref. }\end{array}$ \\
\hline $\begin{array}{l}\text { History of chronic illness } \\
\text { Yes } \\
\text { No }\end{array}$ & $\begin{array}{l}20(54.1) \\
41(35.3)\end{array}$ & $\begin{array}{l}17(45.9) \\
75(64.7)\end{array}$ & 0.043 & $\begin{array}{l}2.152(1.016-4.557) \\
\text { Ref. }\end{array}$ \\
\hline $\begin{array}{l}\text { Family history of chronic illness } \\
\text { Yes } \\
\text { No }\end{array}$ & $\begin{array}{l}21(58.3) \\
40(34.2)\end{array}$ & $\begin{array}{l}15(41.7) \\
77(65.8)\end{array}$ & 0.017 & $\begin{array}{l}2.50(1.160-5.404) \\
\text { Ref. }\end{array}$ \\
\hline $\begin{array}{l}\text { Awareness of health insurance } \\
\text { Yes } \\
\text { No }\end{array}$ & $\begin{array}{l}46(52.9) \\
15(22.7)\end{array}$ & $\begin{array}{l}41(47.1) \\
51(77.3)\end{array}$ & $<0.001$ & $\begin{array}{l}3.815(1.869-7.784) \\
\text { Ref. }\end{array}$ \\
\hline
\end{tabular}

* Unmarried/widow/divorced

Number in parenthesis indicate percentage, $p$ value and COR in bold indicates significance

\section{DISCUSSION}

The mean awareness score was found to be 19.81 with the outcome of $45.1 \%$ aware on the health insurance. The finding was similar to the study conducted in South Africa, ${ }^{7}$ Manipur, India, ${ }^{8}$
Limpopo Province ${ }^{9}$ and Central Karnataka, India ${ }^{10}$ where awareness on health insurance were $52.4 \%$, $62.7 \%, 64 \%$, and $65.7 \%$ respectively. Whereas, dissimilar findings were obtained in few other studies exhibiting high awareness of $75.7 \%$, ${ }^{6}$ $84.4 \%{ }^{11}$ and $98.2 \% .{ }^{12}$ While, the study conducted by Adewole Da et al ${ }^{13}$ and Aderibigbe $S$ et a ${ }^{14}$ showed lower percentage i.e. $6.4 \%$ and $13 \%$ respectively 
were aware about health insurance. This shows that more than half of the respondents were unaware about health insurance scheme which is a growing concern and need to be addressed by all government and non-government agencies working in insurance.

The current study revealed that $39.9 \%$ had enrolled in health insurance which is similar to study done in Maharastra $(38.42 \%),{ }^{15} \quad \operatorname{Karnataka}(45.5 \%)^{10}$ and rural South India(46.9\%). ${ }^{16}$ The enrollment rates in Maharashtra are quoted to be lower with variation across and within the districts. ${ }^{17}$ Study from Nigeria ${ }^{14}$ and Manipur, India ${ }^{8}$ showed lesser percentage with $6.7 \%$ and $9.5 \%$ respectively enrolled themselves in insurance scheme. Since the awareness about health insurance is low this may have resulted in the fewer enrollments in the scheme as both awareness and enrollment are associated.

Among those who enrolled in health insurance, $69.4 \%$ had utilized health service which is analogous to study conducted in Nigeria where $70.1 \%$ of the participants have utilized the health insurance at least once. ${ }^{12}$ A study conducted in Delhi ${ }^{18}$ showed overall utilization of health insurance for health need is $45 \%$. The fact behind this may be explained as the individual get enrolled in the service paying certain amount of premium would have encouraged them to utilize the service.

Majority of the respondents $(88.5 \%)$ had procured government health insurance and $11.5 \%$ procured private health insurance which is similar to the study conducted in Uttar Pradesh showing 80\% of respondents believed in governmental health insurance agencies rather than private insurance companies. ${ }^{19}$ Indumathi $\mathrm{K}$ et $\mathrm{al}^{6}$ also revealed comparable findings with $95.5 \%$ had government insurance and $7.5 \%$ of them had private health insurance. Whereas, study conducted in Karnataka showed $35.06 \%$ procured private health insurance. ${ }^{11}$ As the government health insurance scheme has less premium and beneficiaries for the entire family as compared to other type which might have attracted people to procure this scheme.

The current study showed that there is significant association between ethnicity/caste with awareness on health insurance which is line with study from Maharastra. ${ }^{20}$ Although there is no significant association between awareness with age, gender, type of family, religion, marital status, history of chronic illness and family history of chronic illness which is identical to the study conducted among rural population in Bangalore. ${ }^{6}$ This finding is also in line with study by Temuru J et al. ${ }^{19}$ However contradictory outcome was assimilated from the study of Nigeria suggesting education and gender were significant factors influencing the knowledge and awareness of respondents. ${ }^{21}$

Enrollment in health insurance is also significantly associated with age and ethnicity which is analogous to study conducted in Maharastra. ${ }^{15}$ There is a significantassociation between awareness on health insurance with the enrollment in the scheme with COR(95\% CI); 3.815(1.869 - 7.784) however study conducted in South India ${ }^{16}$ revealed no significant association between awareness on health insurance and being insured. This showed that awareness on the health insurance can play a vital role to raise the percentage enrollment in the health insurance scheme.

The current study showed that there is no association between enrollment with gender, educational level, occupation, monthly family income, type of family. Conversely, study conducted in South India showed male gender, type of family, affordability to pay premium and higher educational status was significantly associated with being insured insurance. Study by Netra et al showed divergent result exhibiting education, occupation and socio economic class is significantly associated with subscription of health insurance. ${ }^{10}$

The study limits the generalization of the findings due to convenient sampling technique and small sample size. Data collection was done during 
office time so the respondents were mostly unemployed and self-employed women and the male respondents were less in number. People residing in that area were recently informed about health insurance by female community health volunteer, so the percentage of awareness on the scheme may have come up more than the actual.

\section{CONCLUSIONS}

Individual awareness and enrollment were poor. The utilization of the health care is also less among those enrolled population. So, there is strong necessity to raise awareness level, convincing them to enroll in any type of scheme based on their

\section{REFERENCES}

1. Memirie ST, Metaferia ZS, Norheim OF, Levin CE, Verguet $S$, Johansson KA. Household expenditures on pneumonia and diarrhea treatment in Ethiopia: a facility-based study. BMJ Global Health. 2017;1: e000166. doi:10.1136/ bmigh-2016-000166..

2. Thuan N, Lofgren C, Chuck N, Janlert U, Lindholm L. Household out-of-pocket payments for illness: Evidence from Vietnam. BMC Public Health. 2006,6:283 doi:10.1186/1471-2458-6-283.9

3. Xu K, Evans DB, Carrin G, Aguilar-Rivera AM, Musgrove P, Evans T. Protecting Households From Catastrophic Health Spending. Health Aff (Millwood). 2007 Jul 1;26(4):972-83

4. Saito E, Gilmour S, Rahman MM, Gautam GS, Shrestha PK, Shibuya K. Catastrophic household expenditure on health in Nepal: a cross-sectional survey. Bulletin of the World Health Organization. 2014;92(10):760-7.

5. Stoermer M, Fuerst F, Rijal K, Bhandari R, Nogier C, Gautam GS, et al. Review of Communitybased Health Insurance ability to pay, ensuring proper utilization of health care after getting enrolled by proactively educating community people. The study also highlighted the insured individual being more inclined towards government health insurance than private which may be because of its beneficial scheme. Thus it is a greater concern for the government as this scheme has started only few years back but its gaining popularity among the citizens.

\section{Acknowledgements}

We are very grateful to all staffs of ward office, community leaders and respondents who participated in the study giving their valuable time and information.

Initiatives in Nepal. Kathmandu: Deutsche Gesellschaft für Internationale Zusammenarbeit (GIZ) GmbH2012.

6. Indumathi $\mathrm{K}$, Saba H, Gopi A, Subramanian M. Awareness of health insurance in a rural population of Bangalore, India. International Journal of Medical Science and Public Health. 2016; 5(10): 2162-7.

7. SetsweG, MuyangaS, Witthuhn J, Nyasulu P. Public awareness and knowledge of the National Health Insurance in South Africa.Pan Afr Med J. 2015; 22(19): 6131. DOI: 10.11604/pamj.2015.22.19.6131.

8. Singh HD, Rudrapal S, Sangma RJB. Awareness on health insurance among an urban community in Imphal: a crosssectional study. J. Evolution Med. Dent. Sci. 2016;5(27):1383-1386, DOI: 10.14260/ jemds/2016/326.

9. Matsi M. Views and Perceptions of Healthcare Workers on the National Health Insurance at Pietersburg -Mankweng Tertiary Hospital, Limpopo Province.National Centre for Biotechnology Information. 2015; 42(1): 1921. 
10. Netra G, Rao BAV. A Study on Awareness, Coverage and Willingness to Avail Health Insurance among the Residents of A Rural Area in Central Karnataka. Natl J Community Med 2019;10(4):190-6.

11. Nayak SK. Awareness and Utilization of Health Insurance among Rural Households in Udupi taluk, Karnataka State, India: A Community Based Study. International Journal of Information Research.2015. Retrieved from: https://www.researchgate.net/ publication/286699839.

12. Ekwuluo CE, Eluwa AN, Okereke IC, Orji SB. Knowledge, Attitudes to, and Utilization of the National Health Insurance Scheme (Nhis) among Health Workers in the University of Nigeria Teaching Hospital(Unth), Ituku-Ozalla, Enugu State, Nigeria.International Journal of Research - Granthaalayah, 6(1), 1-22.DOI: 10.5281/zenodo.1162015.

13. Adewole DA, Adebayo AM, Udeh EI, Shaahu VN, Dairo MD. Payment for Health Care and Perception of the National Health Insurance Scheme in a Rural Area in Southwest Nigeria. Am J Trop Med Hyg. 2015 Sep 2; 93(3): 648-54. DOI: 10.4269/ajtmh.14-0245.

14. Adedeji AS, Doyin A, Kayode OG, Ayodele AA. Knowledge, Practice and Willingness to Participate in Community Health Insurance Scheme among Households in Nigerian Capital City. Sudan Journal of Medical Sciences. 2017; 12(1): 9-18. DOI: 10.18502/sjms.v12i1.854.

15. Rathi P, Mukherji A, Sen G. Rashtriya Swasthya Bima Yojana: evaluating utilisation, roll-out and perceptions in Amravati district, Maharashtra. Econ
Polit Wkly (2012) 47(39):57-64.

16. Sudhir, Chaitra M, Deepa K. Determinants of Health Insurance in rural population of South India. Indian Journal of Forensic and Community Medicine, July September 2015;2(3):172-5

17. Sun C. An analysis of RSBY enrolment patterns: preliminary evidence and lessons from the early experience. In: Palacios R, Das J, Sun C, editors. India's Health Insurance Scheme for the Poor: Evidence from the Early Experience of RSBY. New Delhi: Centre for Policy Research (2011). p. 84-116.

18. Kusuma YS, Pal M, Babu BV. Health Insurance: Awareness, Utilization, and its Determinants among the Urban Poor in Delhi, India. National Centre for Biotechnology Information.2018; 8(1): 6976.

19. Temuru J, Olufunlayo T, Onajole AT. Knowledge and attitude of public secondary school teachers towards community based Health insurance. Academia education. 2014. Retrieved from: https://www.academia. edu/7057283/knowledge_and_of_public_ secondary_school_teachers_towards_ community_based_health_insurance.

20. Thakur H. Study of Awareness, Enrollment, and Utilization of Rashtriya Swasthya Bima Yojana in Maharashtra, India. Frontiers in Public Health Jan 2015; 7(3): 282.

21. Ogben C, Ilesanmi O. Community based health insurance scheme: Preferences of rural dwellers of the federal capital territory Abuja, Nigeria. J Public Health Afr. 2018 May 21; 9(1): 540. DOI: 10.4081/ jphia.2018.540

Citation: Sharma D, Basnet P, Kafle R. Awareness, Enrollment and Utilization of Health Insurance among Adults of Pokhara. JCMS Nepal. 2021; 17(2); 109-16. 